\title{
Phytophthora sojae TatD Nuclease Positively Regulates Sporulation and Negatively Regulates Pathogenesis
}

\author{
Linlin Chen, Danyu Shen, Nannan Sun, Jing Xu, Wen Wang, and Daolong Dou \\ Department of Plant Pathology, Nanjing Agricultural University, Nanjing, 210095, China
}

Submitted 25 May 2014. Accepted 5 June 2014.

\begin{abstract}
During pathogenic interactions, both the host and pathogen are exposed to conditions that induce programmed cell death (PCD). Certain aspects of PCD have been recently examined in eukaryotic microbes but not in oomycetes. Here, we identified conserved TatD proteins in Phytophthora sojae; the proteins are key components of DNA degradation in apoptosis. We selected PsTatD4 for further investigation because the enzyme is unique to the oomycete branch of the phylogenetic tree. The purified protein exhibited DNase activity in vitro. Its expression was upregulated in sporangia and later infective stages but downregulated in cysts and during early infection. Functional analysis revealed that the gene was required for sporulation and zoospore production, and the expression levels were associated with the numbers of hydrogen-peroxide-induced terminal dUTP nick end-labeling-positive cells. Furthermore, overexpression of PsTatD4 gene reduced the virulence in a susceptible soybean cultivar. Together, these data suggest that apoptosis may play different roles in the early and late infective stages of $P$. sojae, and that PsTatD4 is a key regulator of infection. The association of PsTatD4 and apoptosis will lay a foundation to understanding the basic biology of apoptosis and its roles in $P$. sojae disease cycle.
\end{abstract}

Apoptosis or apoptosis-like cell death is a type of programmed cell death (PCD) and is characterized by an orderly sequence of events: cell shrinkage, membrane blebbing, chromatin condensation, and DNA fragmentation or degradation (Williams and Dickman 2008). In eukaryotic microbes, apoptosis is important in the regulation of normal development and differentiation, maintenance of cellular homeostasis, removal of damaged cells, and the response to infectious agents or stressors (Madeo et al. 1999; Sharon et al. 2009). Apoptosis networks are composed of hundreds of proteins. For example, the caspases are initially synthesized as inactive proenzymes and become activated via proteolytic cleavage at internal aspartate residues when cells receive apoptosis-inducing signals (Nicholson and Thornberry 1997). One hallmark of terminal apoptosis is DNA fragmentation and degradation by endo- or exonucleases. Such cleavage can be measured using the terminal dUTP nick endlabeling (TUNEL) method (Galluzzi et al. 2009). To date, three major types of nucleases have been

Corresponding author: D Dou; Telephone: +86-025-84396973; Fax: +86025-84395325; E-mail: ddou@njau.edu.cn

* The $\boldsymbol{e}$-Xtra logo stands for "electronic extra" and indicates that four supplementary figures and two supplementary tables are published online and that Figures 1, 4, and 7 appear in color online.

(C) 2014 The American Phytopathological Society characterized in human and Caenorhabditis elegans, including DFF40/caspase-activated DNase (Liu et al. 1999), Cps-6/endonuclease G (caspase-independent) (Parrish and Xue 2003), and Nuc 1/DNase II (Lyon et al. 2000). In addition, seven and eight nucleases exhibiting distinct activities and substrate specificities have been identified in C. elegans (Parrish and Xue 2003) and Saccharomyces cerevisiae (Qiu et al. 2005), respectively. Of these enzymes, TatD is likely to exhibit the greatest extent of conservation across all kingdoms (Qiu et al. 2005).

The TatD gene was initially identified in Escherichia coli, and is part of a four-cistron operon (with $t a t A / B / C$ genes). TatA/B/C are required for the operation of the twin-arginine translocation (Tat) system mediating transport of proteins that contain a consensus "twin arginine" signal peptide (Weiner et al. 1998). However, TatD is not involved in this process; rather, it exhibits magnesium-dependent DNase activity in E. coli (Wexler et al. 2000). TatD is an important apoptotic component by virtue of the nuclease activity in S. cerevisiae. Knockout of the gene in yeast increases the proportion of cell survival in response to hydrogen peroxide $\left(\mathrm{H}_{2} \mathrm{O}_{2}\right)$ treatment, and gene overexpression facilitates cell death (Qiu et al. 2005). TatD also plays a role in apoptotic DNA degradation in other organisms, such as C. elegans (Parrish and Xue 2003), Leishmania spp. (BoseDasgupta et al. 2008), and Trypanosoma brucei (Gannavaram and Debrabant 2012). The TatD nuclease probably complexes with endonuclease $\mathrm{G}$ (EndoG) to form a DNA "degradosome" that is an essential component of a caspaseindependent PCD pathway (BoseDasgupta et al. 2008; Gannavaram and Debrabant 2012). However, the functions and mechanisms of action of the TatD enzymes of other organisms remain largely unknown, and the relevance of enzyme activity in terms of parasite virulence remains to be established.

It is important to understand parasite PCD, including apoptosis, because useful antifungal drugs and fungicides may activate fungal cell suicide if differences in the death machineries of pathogens and their hosts can be identified (Ramsdale 2008). The PCD pathways of human pathogenic fungi (e.g., Candida albicans) and autophagic cell death of the model plant pathogen Magnaporthe grisea are relatively well-understood (Veneault-Fourrey et al. 2006). However, the apoptotic pathways of filamentous plant pathogens, including fungi and oomycetes, remain poorly known. Infected hosts produce many compounds that can induce apoptosis of pathogens, and successful invasion may escape from the apoptosis-inducing defense machinery of the host. For example, Colletotrichum gloeosporioides strains expressing the anti-apoptotic BCL-2 protein exhibited increased resistance to $\mathrm{H}_{2} \mathrm{O}_{2}$-induced stress and were hypervirulent, indicating that enhanced resistance to apoptosis improved the ability of the pathogen to infect the host (Barhoom and Sharon 2007). In Botrytis cinerea, a plant necrotrophic fungus, the intestinal alkaline phosphatase-like 
protein BcBir1, part of the anti-apoptotic system, protected the fungus from host-induced PCD to allow initial infection to be established (Shlezinger et al. 2011). PCD of C. gloeosporioides spores does not occur during infection (Nesher et al. 2008) whereas autophagic cell death is necessary for infection by $M$. grisea (Veneault-Fourrey et al. 2006). It remains unclear whether pathogen PCD, especially apoptosis, is involved in development of pathogenicity.

Many economically important eukaryotic plant pathogens, such as Phytophthora sojae, belong to the oomycetes, which are distinct from fungi and classified in the kingdom Stramenopiles, although exhibiting many morphological and physiological similarities to fungi attributable to convergent evolution (Rossman and Palm 2006). Phytophthora plant pathogens attack a wide variety of plants, causing great losses in agriculture, forestry, and natural ecosystems worldwide (Erwin and Ribiero 1996). Asexual sporangia (or zoosporangia) or zoospores of Phytophthora play essential roles in disease cycles, being involved in both initial infection and transmission of the pathogen from host to host (Walker and van West 2007). The sporangia of $P$. infestans, a notorious pathogen, germinate directly; hyphae emerge through the sporangial wall to commence infection (Judelson and Blanco 2005). Sporangia of other species, such as $P$. sojae, germinate via a zoospore pathway. Zoospores are released from sporangia and attracted by chemotaxis toward host roots. Then, the zoospores transfer into walled cysts that germinate to produce a hypha for infection (Tyler 2007). When the health of a colonized plant declines, sporangia or zoospores develop and move to another new host (Judelson and Blanco 2005). In addition, Phytophthora spp. are hemibiotrophic pathogens, in which an initial biotrophic phase is followed by a necrotrophic phase (van Damme et al. 2011). Although the physiological and genetic mechanisms of sporulation, spore germination, and hemibiotrophic disease cycles have been well-studied, any association of apoptotic-like cell death with such processes has not been observed.

In the present work, we analyzed the TatD gene family in $P$. sojae and found that TatD4 was unique to oomycetes. PsTatD4 exhibited DNase activity that is a component of apoptosis. PsTatD4 overexpression increased TUNEL-positive cells, a marker of PCD. PsTatD4 was expressed in sporangia and later infective stages but not in cysts or at early stages of infection. Notably, alterations in PsTatD4 expression in P. sojae transgenic lines had opposite effects on sporulation and virulence. It appears that this protein might be a key regulator of sporulation and pathogenesis in the Phytophthora pathogens.

\section{RESULTS}

TatD nucleases are conserved in oomycetes.

To identify Tat protein candidates in $P$. sojae, the sequences of TatA/B/C/D/E proteins from humans, bacteria, and fungi were retrieved and used to conduct a BLAST search of oomycete genomes. No TatA/B/C/E homologues were found in $P$. sojae (data not shown), suggesting that the species may lack the Tat secretion pathway. However, four TatD candidates were identified in $P$. sojae, and all contained the conserved DNase domain (Supplementary Fig. S1). We termed the proteins PsTatD1 (Ps350745), PsTatD2 (Ps310392), PsTatD3 (Ps262447), and PsTatD4 (Ps495397), with reference to the phylogenetic tree (Fig. 1; Supplementary Table S2). Four corresponding TatD proteins were identified accordingly in all the tested oomycete pathogens: $P$. ramorum, $P$. infestans, $P$. capsici, Hyaloperonospora arabidopsidis, and Pythium ultimum.

We constructed a phylogenetic tree of TatD proteins focusing on data from the six oomycetes, E. coli, S. cerevisiae, T. brucei, Homo sapiens, and Arabidopsis thaliana. Three significant branches were evident (Fig. 1). The first included the TatD1 proteins of all examined organisms except $E$. coli, and a duplicate was present in Hyaloperonospora arabidopsidis and A. thaliana. The second branch included the TatD2 proteins of most eukaryotes. The third branch could be divided into two sub-branches separately containing the TatD3 and TatD4 proteins. The TatD3 branch included sequences from five of the six oomycete species, and clustered only with the E. coli TatD3 protein. However, the TatD4 branch was unique to oomycetes (no TatD4 sequence was present in the other organisms), raising the question as to why TatD4 exists only in oomycetes. Thus, we analyzed the roles played by TatD 4 in the development and virulence of Phytophthora sojae.

\section{PsTatD4 is a DNase.}

Because the TatD proteins of E. coli (Wexler et al. 2000), $S$. cerevisiae (Qiu et al. 2005), and T. brucei (Gannavaram and Debrabant 2012) proteins exhibit DNase activity, we explored the activity of recombinant PsTatD4 produced in E. coli. An approximately $47-\mathrm{kDa}$ soluble protein was specifically purified for fusion protein, which consisted of PsTatD4 and tags for purification. As a control, an approximately 19-kDa protein was purified from the empty pET-32a(+) vector (Fig. 2A). DNase activities on $P$. sojae genomic DNA and plasmid sub-

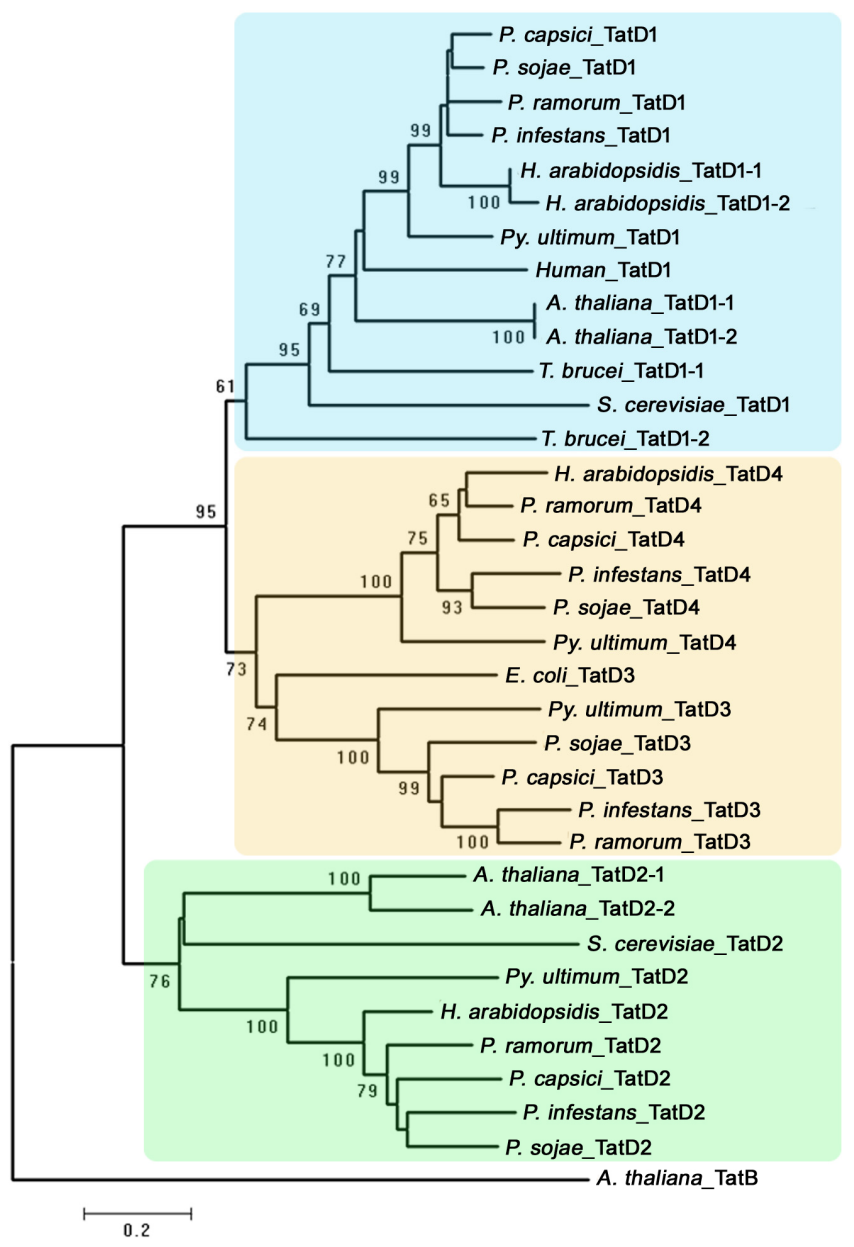

Fig. 1. Phylogenetic relationship of TatD proteins. The phylogenetic tree includes TatD proteins identified from Phytophthora sojae, P. ramorum, P. infestans, P. capsici, Hyaloperonospora arabidopsidis, Pythium ultimum, Saccharomyces cerevisiae, Trypanosoma brucei, Arabidopsis thaliana, Homo sapiens, and Escherichia coli. Three clustered branches are displayed by different translucent colors. Values at nodes (only $>60$ are displayed) represent the bootstrap support value in percent of 1,000 replicates. 
strates were evaluated. PsTatD4 efficiently degraded the DNAs whereas a control lysate did not (Fig. 2B). Furthermore, we separately mutated two key conserved residues (H186 and $\mathrm{H} 215)$ that are required for DNase activity for characterizations (Gannavaram and Debrabant 2012). We found that both mutated proteins were well produced in E. coli (Fig. 2A) and exhibited significantly reduced DNase activity (Fig. 2B). Thus, PsTatD4 has a DNase activity.

\section{Expression of the PsTatD4 gene is regulated} during sporulation and infection.

Expression of the PsTatD4 gene was examined by expressing a $2-\mathrm{kb}$ intergenic region upstream of the open reading frame to the $\beta$-glucuronidase (GUS) reporter in $P$. sojae. GUS was weakly detected in cultured mycelia, being enriched in sporangia, but was very poorly expressed in cysts and germinating cysts. At the infection process, GUS was not detectable at the early stages (6 and $12 \mathrm{~h}$ postinfection [hpi]) but appeared at later stages ( 24 to $72 \mathrm{hpi}$ ). A number of sporangia were induced at $72 \mathrm{hpi}$, while PsTatD4 was highly expressed in sporangia (Fig. 3). Furthermore, the relative expression lev- els of PsTatD4 gene were validated by quantitative reversetranscriptase polymerase chain reaction (qRT-PCR). The transcriptional levels of PsTatD4 escalated in sporangia and the later stages (36 to $72 \mathrm{hpi}$ ), and the maximum level of induction was observed at 48 hpi (Supplementary Fig. S2), which are comparable to the GUS staining assay. Thus, the gene was upregulated in sporangia and later infection stages and downregulated in cysts and during the early stages of infection, indicating that the gene might play important roles in both sporulation and virulence.

\section{Construction of transgenic lines.}

To explore potential effects of PsTatD4, we generated PsTatD4-overexpressing and PsTatD4-silencing transgenic lines using a polyethylene glycol-mediated protoplast stable transformation method in P. sojae (Dou et al. 2008; McLeod et al. 2008). The plasmid with sensing PsTatD4 construct driven by the constitutive Ham34 promoter was used for transformation, leading to different transformant increase or decrease expressional levels of the targeted gene (Song et al. 2013). The required transformants were preliminarily identified via ge-
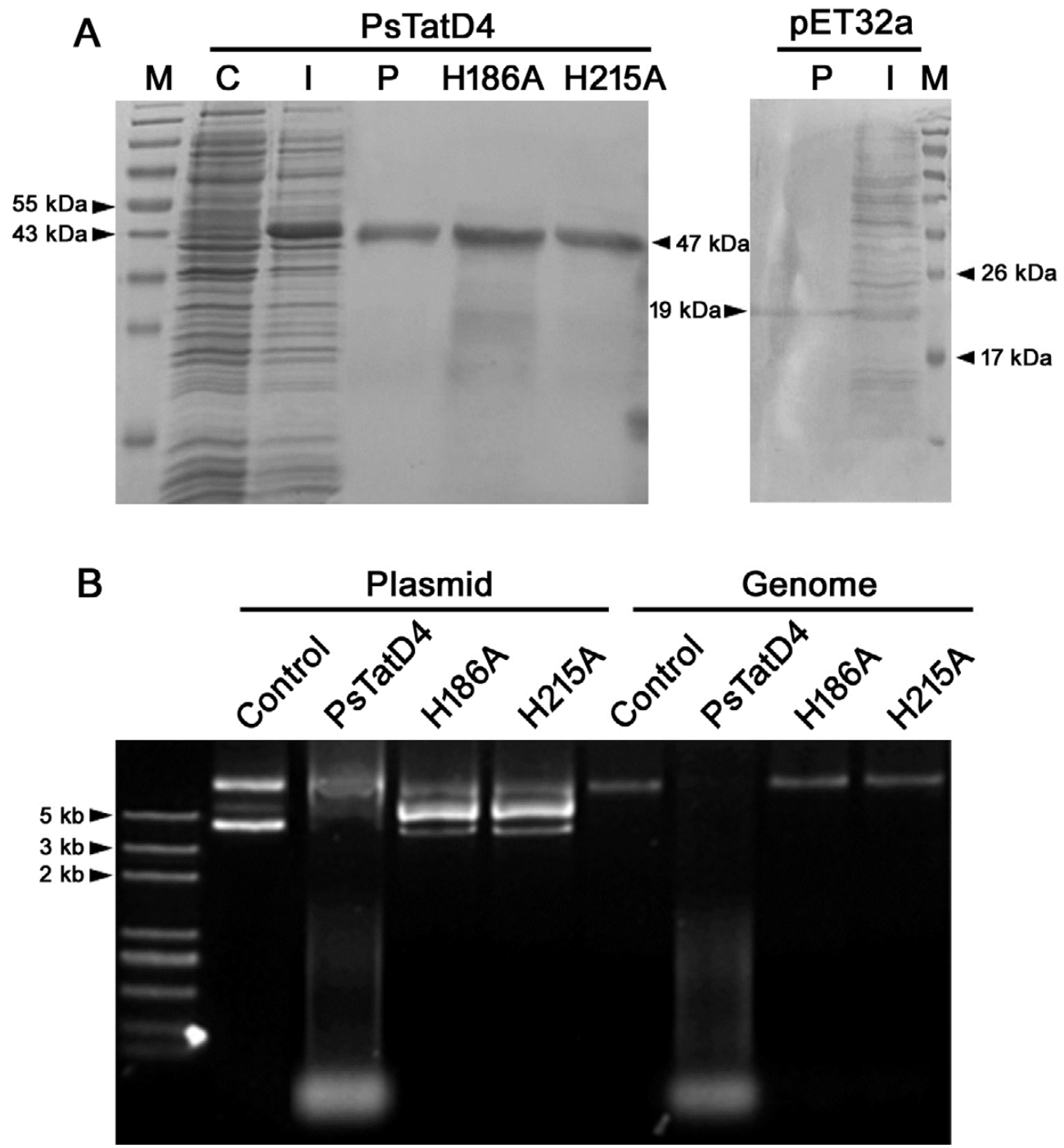

Fig. 2. Purified PsTatD4 exhibits DNase activity in vitro. A, Purification of PsTatD4 and its mutated proteins in Escherichia coli. Sodium dodecyl sulfate polyacrylamide gel electrophoresis was used to visualize material from E. coli BL21 transformed with a PsTatD4, mutated PsTatD4-expressing plasmid (left), or the empty vector pET-32a(+) (right). The gel was stained with Coomassie blue. Lane $\mathrm{C}=$ no isopropyl-thio-galactopyranoside (IPTG) induction as control, I = with IPTG induction, P = purified protein, H186A = PsTatD4 H186A mutated protein, H215A = PsTatD4 H215A mutated protein. B, Nuclease cleavage assay of PsTatD4 and its mutated proteins. Ethidium-bromide-stained gel shows the cleavage products of PsTatD4 and two mutated proteins (H186A and H215A) with Phytophthora sojae genomic DNA and pET-32a(+) plasmid DNA as substrates. 
nomic PCR analysis (Fig. 4A), and the expression levels of the targeted genes were measured using qRT-PCR. The PsTatD4 gene transcription levels increased by up to 30 -fold in a transgenic line OT421 compared with the wild type (WT) and was reduced to $10 \%$ of the WT value in another line, ST405 (Fig. 4B). We noticed that gene PsTatD3 in OT421 was higher than in the WT and CK (T370). Considering that its expressional levels are extremely low (approximately 1\% of the other three genes), we conclude that PsTatD4 gene is specifically silenced in ST405 and highly overexpressed in OT421. Western blotting also confirmed that the PsTatD4 protein was successfully overexpressed in OT421 and the protein was stable (Fig. 4C). In addition, we designed a full-length PsTatD4 construct fused C-terminally with green fluorescent protein (GFP), and transformed it into $P$. sojae. A transgenic line (PsTatD4-GFP; OT11) was obtained by validation using qRT-PCR (Fig. 4B), confocal observation (Fig. 4D), and Western blotting (Supplementary Fig. S3). The growth rate of the PsTatD4-silenced strain (ST405) was similar to that of the WT and control strains, whereas those of PsTatD4-overexpressing strains (OT421 and OT11) were significantly reduced (Fig. 4E). Thus, we constructed two independent overexpressing and one silenced transgenic lines.

\section{Changes in PsTatD4 expression levels affect sporulation and zoospore production.}

Sporangial development was compared among WT and recombinant $P$. sojae, including a transgenic line (T370) as a control in which the gene expressional levels are the same as the WT. The PsTatD4-overexpressing lines (OT421 and OT11)

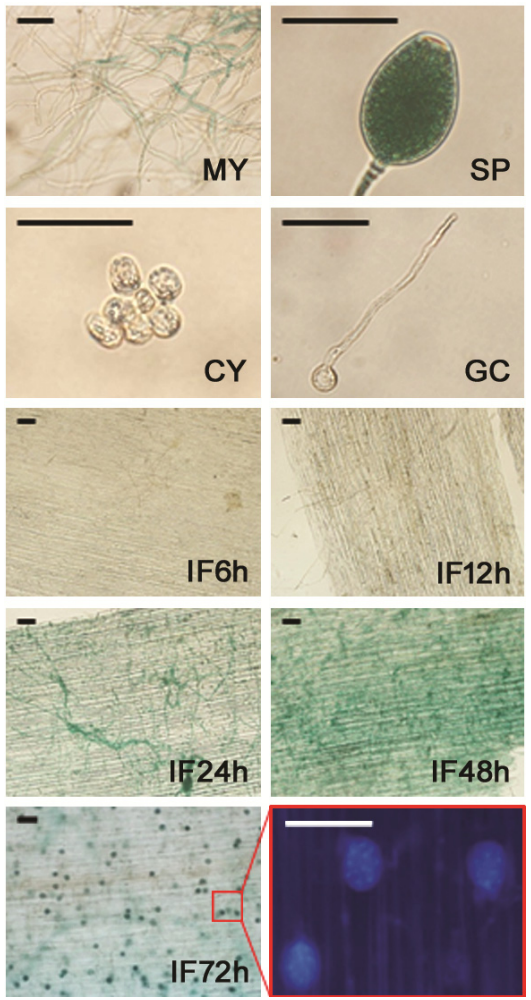

Fig. 3. Expression of PsTatD4 promoter- $\beta$-glucuronidase (GUS) in Phytophthora sojae. GUS activities of a transgenic $P$. sojae strain hosting the 2-kb PsTatD4 promoter-GUS construct were visualized at different stages of development and infection by staining with 5-bromo-4-chloro-3indolyl-b-D-glucuronide. At $72 \mathrm{~h}$ postinfection (hpi), 4',6-diamidino-2phenylindole staining of nuclei in sporangia was shown. MY = mycelia; $\mathrm{SP}=$ sporangia; $\mathrm{CY}=$ cysts; $\mathrm{GC}=$ germinating cysts; $\mathrm{IF} 6 \mathrm{~h}$ to $\mathrm{IF} 72 \mathrm{~h}=6$, $12,24,48$, and 72 hpi of soybean etiolated seedlings. Bars $=50 \mu \mathrm{m}$. showed significant elevations in sporangial production whereas the reverse was true of the silenced line (ST405) (Fig. $5 \mathrm{~A}$ and $\mathrm{B})$. Zoospore production from sporangia of OT421 and OT11 was more efficient than that of the WT; $70 \%$ of sporangia released all zoospores after $12 \mathrm{~h}$ of sporangial induction. In contrast, only 29 and $14 \%$ of the WT and CK (T370) sporangia, respectively, had released, whereas almost no sporangia of ST405 began to release (Fig. 5A). The numbers of zoospores produced by OT421 and OT11 accordingly increased, and those from ST405 dramatically fell, compared with WT and CK (T370) (Fig. 5C). Notably, we found that overexpression of PsTatD4 triggered a high number of abnormal sporangia, which was seldom evident in the WT, CK (T370), or ST405 (Fig. 5D). However, no among-strain difference was evident in terms of zoospore encystment and cysts germination (data not shown). These results suggested that PsTatD4 positively regulates sporulation and zoospore production.

\section{Overexpression of PsTatD4 reduces virulence.}

To determine whether PsTatD4 affected the virulence of $P$. sojae, we inoculated etiolated seedlings of the susceptible soybean 'Williams' with zoospore suspensions of WT, CK (T370), OT421, OT11, and ST405. Upon infection with OT421 or OT11, the lesion sizes were reduced by $59.15 \pm 1.7$ and 58.37 $\pm 0.56 \%$, respectively (compared with two controls: WT and T370). In contrast, the two controls and ST405 were normal in terms of pathogenesis; no obvious among-strain difference was apparent (Fig. 6A and B). Next, we performed a leaf-inoculation assay to validate these results. The overexpressing strains were less virulent than the two controls and the silenced line (Fig. 6C and D). Thus, overexpression of PsTatD4 reduced virulence.

To exclude the possibility that the observed reduction in virulence was a consequence of a reduction in growth rate (Fig. 4E), we subjected hyphae-infecting soybean epidermal cells to trypan blue staining (Fig. 6E). Many infected hyphae and finger-like haustoria were observed upon infection with WT or ST405. In contrast, no OT421 hyphae were observed in the infected soybean epidemical cells. Rather, many papillae were evident at the interface between the pathogen and the soybean, indicating that hyphal penetration was impaired (Fig. $6 \mathrm{E})$. Thus, the reduced virulence of the OT421 line seems to be attributable to the loss of the ability to penetrate host cells.

\section{PsTatD4 is involved in $\mathrm{H}_{2} \mathrm{O}_{2}$-induced PCD in $P$. sojae via relocalization to nuclei.}

To explore whether PsTatD4 expression affected PCD of $P$. sojae, we treated zoospores of WT, CK (T370), ST405, and OT421 strains with $\mathrm{H}_{2} \mathrm{O}_{2}$, which induces apoptosis in yeast at low concentrations (Madeo et al. 1999). Apoptotic DNA degradation in zoospores was quantitated with the aid of the TUNEL assay, which has been used to study apoptosis in bacterial, fungal, and plant cells (Galluzzi et al. 2009). The number of TUNEL-positive cells of OT421 was significantly higher and that of ST405 significantly lower than the numbers of WT and CK cells (Fig. 7A). TUNEL-positive cells were visible by fluorescence microscopy in $\mathrm{H}_{2} \mathrm{O}_{2}$-treated cells (Fig. 7B). OT421 grew more slowly than the WT and control (T370) strains in the absence of $\mathrm{H}_{2} \mathrm{O}_{2}$ (Figs. 4E and 7C). This might be caused by the overexpressing of PsTatD4, which led to increased TUNEL-positive cells (Fig. 7A). However, the sensitivity of OT421 to $\mathrm{H}_{2} \mathrm{O}_{2}$ was similar to that of the control and silenced line (Fig. 7C).

To localize PsTatD4, we used confocal microscopy to examine the OT11 and GFP7 lines bearing GFP fused to PsTatD4 and GFP alone, respectively (Fig. 4D). PsTatD4 was located in the cytoplasm and, thus, almost absent from the 
nuclei of both mycelia and sporangia (Figs. 4D and 8A; Supplementary Fig. S4), as is also true of $T$. brucei homologs (Gannavaram and Debrabant 2012; Qiu et al. 2005). However, $\mathrm{H}_{2} \mathrm{O}_{2}$ treatment caused PsTatD4 to be translocated from the cytosol to the nucleus in both mycelia and sporangia (Fig. 8B). In contrast, the distribution of fluorescent signals in the GFP7 line was not affected by $\mathrm{H}_{2} \mathrm{O}_{2}$ treatment (Fig. $8 \mathrm{C}$ and D). We also confirmed whether the fusion proteins are intact during

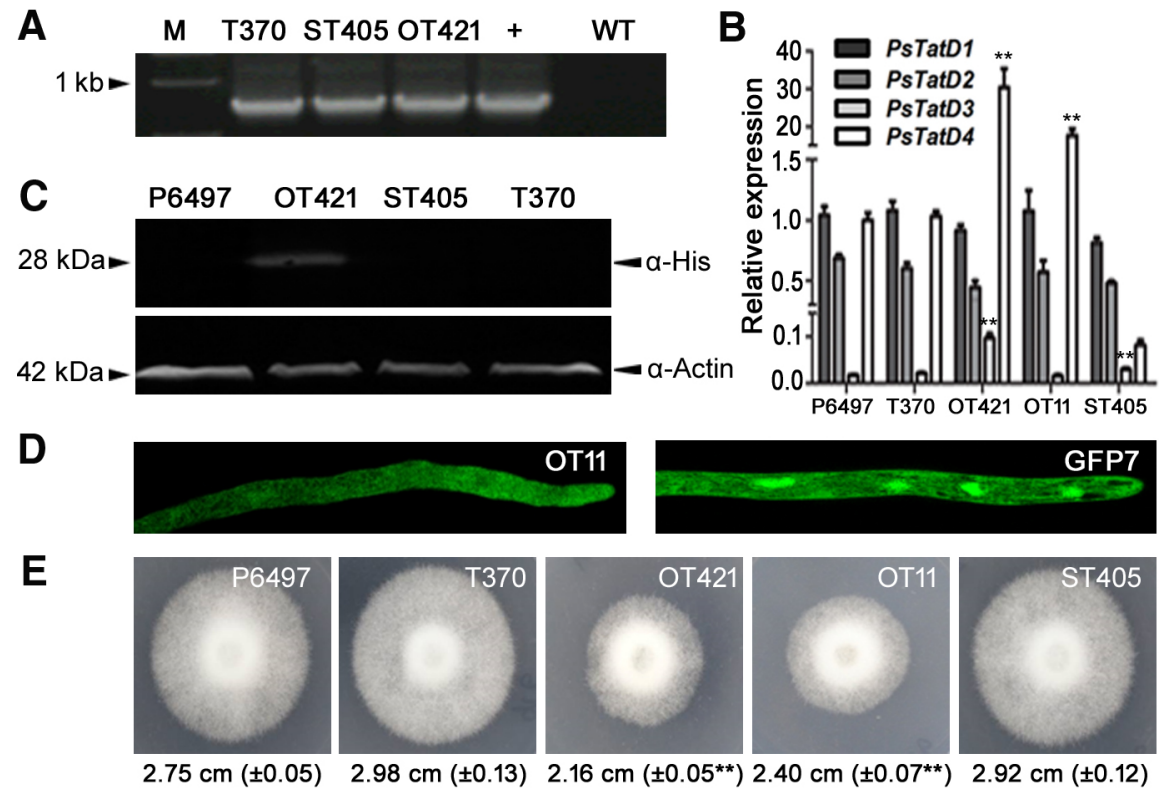

Fig. 4. Construction of PsTatD4-transgenic lines. A, Verification of incorporation into genomic DNA by polymerase chain reaction (PCR) using oligonucleotides from the Ham34 promoter and terminator regions as primers. The transgene should yield an amplified fragment $747 \mathrm{bp}$ in length. Lanes: $+=$ plasmid DNA, WT = wild-type strain P6497, and M = molecular markers. B, Quantitative reverse-transcriptase PCR measurement of the relative transcript levels of four PsTatD genes in control (P6497 and T370), overexpressing (OT421 and OT11), and silenced (ST405) transformants. Relative expression levels are calculated using TEF1 as the reference gene. Bars indicate standard errors and stars above bars indicate that the significant difference from the wild-type value; ** indicates $P<0.01$ ( $t$ test). C, Western blotting of PsTatD4 from transformed mycelia. Total protein was extracted from mycelia grown in vitro. PsTatD4 was detected with anti-His antibody (upper panel) while the protein amounts were normalized using anti-Actin antibody (bottom panel). PsTatD4 protein is approximately $28 \mathrm{kDa}$. D, Green fluorescent protein (GFP) fluorescence from the PsTatD4-GFP fusion protein (left, OT11) and GFP alone (right, GFP7). E, Reduced mycelial growth of PsTatD4-overexpressing strains. Colony diameters were measured after Phytophthora sojae culture on 10\% V8 solid medium for 3 days at $25^{\circ} \mathrm{C}$ in the dark. Data shown are representative of four colonies in each of three independent experiments. Standard errors were marked in brackets; ** indicates $P<0.01$ ( $t$ test).

\section{A}

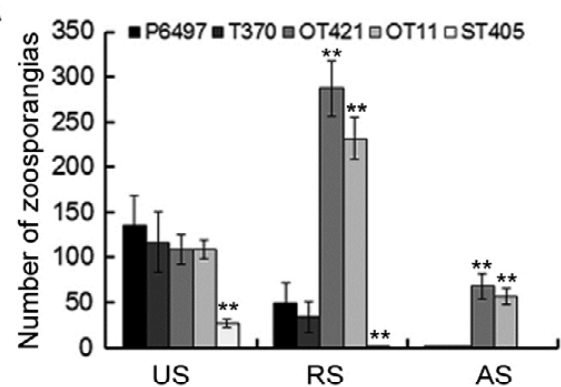

C

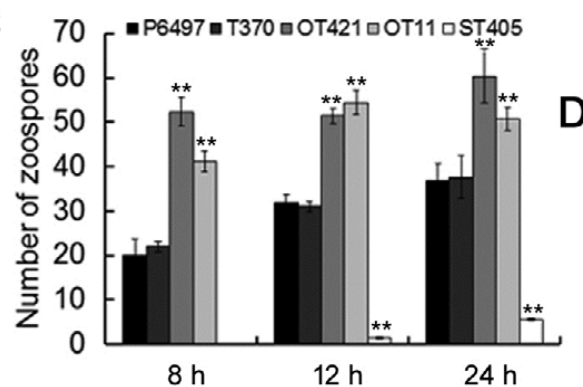

B
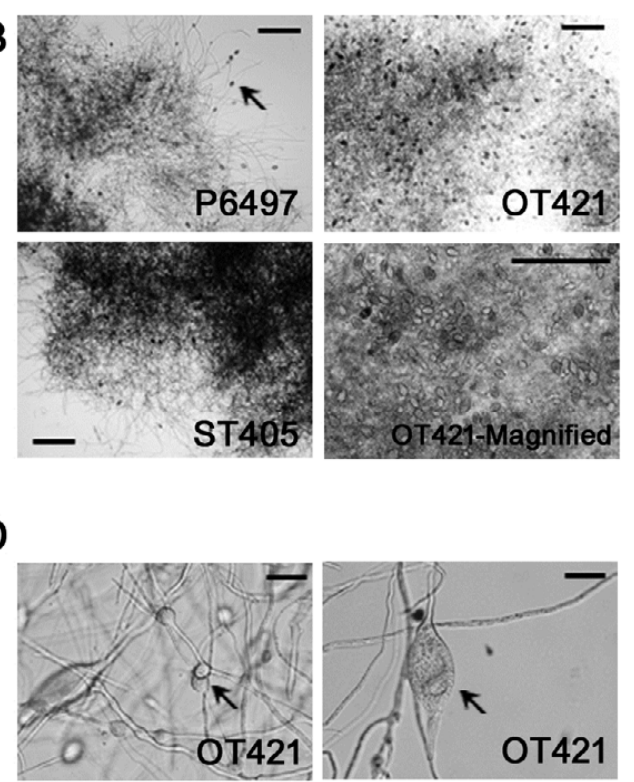

Fig. 5. Phytophthora sojae sporangial production is regulated by PsTatD4. A, Numbers of sporangia produced by $P$. sojae transgenic lines. Sporangia of the indicated samples were counted $12 \mathrm{~h}$ after induction of sporangial production. Data shown are representative of those of three separate experiments. Bars indicate standard errors and stars above bars indicate that the difference from the wild-type (WT) value was significant; $* *$ indicates $P<0.01(t$ test). US $=$ unreleased sporangia, $\mathrm{RS}=$ released sporangia, and AS = abnormal sporangia (as shown in D). B, Sporangial phenotypes of $P$. sojae transgenic lines. Micrographs were taken $12 \mathrm{~h}$ after sporangial induction and black arrows indicate sporangia. Bars $=500 \mu \mathrm{m}$. C, Numbers of zoospores produced. Zoospores were counted 8, 12, and $24 \mathrm{~h}$ after sporangial induction. All experiments were repeated three times with similar results. Bars indicate standard errors and stars above bars indicate that the significant difference from the WT; ** indicates $P<0.01(t$ test $)$. D, Abnormal zoosporangia of the OT421 line. Bars $=100 \mu \mathrm{m}$. 
$\mathrm{H}_{2} \mathrm{O}_{2}$ treatment by Western blotting assay. No difference of free GFP among the treatments were observed. These results indicate that PsTatD4 may translocate from the cytoplasm to the nucleus during $\mathrm{H}_{2} \mathrm{O}_{2}$-induced apoptosis.

\section{DISCUSSION}

When plants and their pathogens interact, each attempts to manipulate the other using a complex network to maximize their respective survival probabilities. PCD processes, including apoptosis, feature prominently in such interactions and may benefit either the host or the pathogen, depending on the balance attained (Narasimhan et al. 2001; Shlezinger et al. 2012). Plant PCD is crucial in terms of resistance to pathogens, and has been well-studied (del Pozo and Lam 1998; Lam 2004; Mittler and Lam 1996). The resistance also may be influenced by pathogen viability, controlled by host molecules. For example, a $P$. sojae infection begins when the zoospores are released from sporangia and become appropriately located on the surface of soybean tissues. The commitment of pathogenic cells to germination or to death is assumed to be critical in terms of the success of infection. Recent studies have shown that fungal pathogens indeed undergo apoptosis (Barhoom and Sharon 2007; Shlezinger et al. 2011) but the role played by such PCD in Phytophthora pathogens remains poorly understood, and the nature of regulation of apoptotic cell death is unknown. In the present work, we studied the effect of the TatD protein, an apoptotic component, on the pathogenesis of and sporulation in $P$. sojae by alteration of its expressional levels.

TatD is highly conserved across all the organisms and exhibits nuclease activity, and fragmenting and degrading DNA in the terminal stages of apoptosis (Qiu et al. 2005). We identified four conserved TatD homologs in oomycetes, one of which was unique to such organisms. TatD may translocate from the cytoplasm to the nucleus upon PCD induction, forming a complex with EndoG creating DNA degradosome in Trypanosoma and Leishmania spp. EndoG knockdown inhibited caspase-independent PCD in Leishmania spp. (BoseDasgupta et al. 2008), and overexpression of the TatD nuclease elevated PCD in Trypanosoma spp. (Gannavaram and Debrabant 2012). However, the roles played by these enzymes in pathogenesis have not been addressed in these human parasites. We found that overexpression of PsTatD4 in P. sojae increased the numbers of TUNEL-positive cells evident in the presence or absence of exposure to $\mathrm{H}_{2} \mathrm{O}_{2}$, and that expressional reduction of the gene also reduced TUNEL-positive cells upon $\mathrm{H}_{2} \mathrm{O}_{2}$ treatment. Notably, overexpression of PsTatD4 clearly reduced the virulence of $P$. sojae. PsTatD4 has DNase activity and is transferred from the cytoplasm to the nucleus upon exposure to $\mathrm{H}_{2} \mathrm{O}_{2}$, probably explaining the involvement of PsTatD4 in apoptosis: the DNase degrades DNA in cells undergoing PCD. Whole-genome analysis showed that $P$. sojae lacked caspaselike genes but contained genes encoding EndoG and an apoptosis-inducing factor (AIF) (data not shown). Thus, we suggest that PsTatD4 may play an important role in apoptosis of $P$. sojae cells, perhaps via a caspase-independent pathway. A nuclease complex containing EndoG, TatD, and other proteins may be present in nuclei of species of Trypanosoma (BoseDasgupta et al. 2008) and Leishmania (Gannavaram and Debrabant 2012). It is important to identify other apoptotic nucleases and to determine whether TatD interacts with such nucleases to form a DNA-degradation complex in P. sojae.

Overexpression of PsTatD4 reduced $P$. sojae virulence, suggesting that it may negatively regulate pathogenesis in $P$. sojae. It was shown that $P$. parasitica zoospores undergo PCD at the infection sites of wounded Nicotiana tabacum leaves.
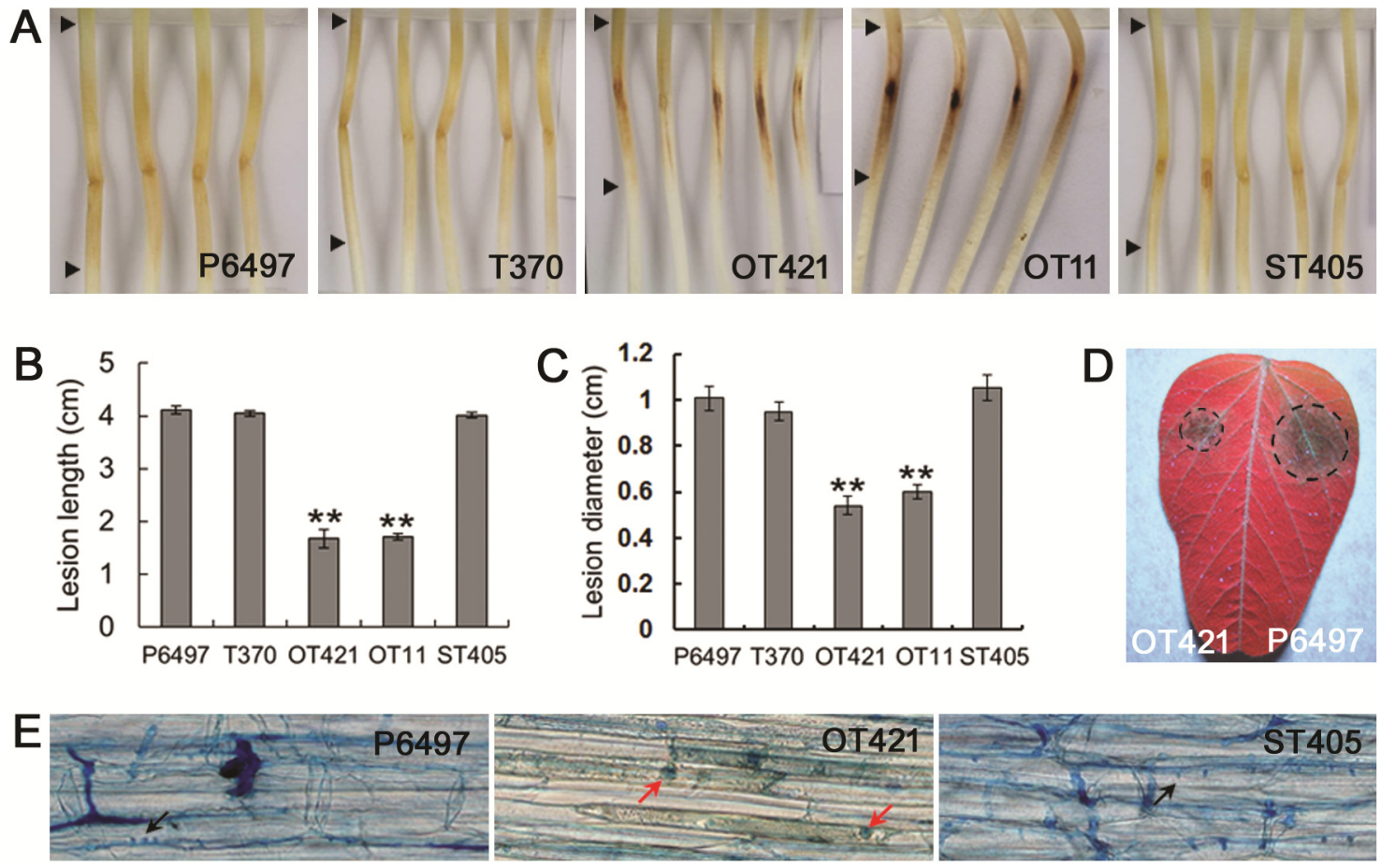

Fig. 6. PsTatD4 overexpression reduces virulence of Phytophthora sojae. A, Phenotypes of soybean etiolated seedlings inoculated with wild-type $P$. sojae and recombinant strains. Approximately 200 zoospores were used for each inoculation. Photographs were taken $36 \mathrm{~h}$ postinfection (hpi) and lesions edges are indicated by arrows. B, Lesion lengths measured at 36 hpi on five seedlings in each of four independent experiments. Bars indicate the standard errors; ** indicates $P<0.01$ ( $t$ test). C, Lesion diameters on soybean leaves. Leaves of the susceptible soybean 'Williams' were inoculated with zoospores and lesion diameters were measured at $30 \mathrm{hpi}$ on five leaves in each of three independent experiments. Bars indicate the standard errors; $* *$ indicates $P<0.01(t$ test). D, Comparison of the phenotypes of soybean leaves inoculated with the wild-type and a PsTatD4-overexpressing transformant (OT421). A typical photograph taken at 30 hpi was shown as an example. E, Trypan blue staining of hyphae infecting soybean epidermal cells. Photographs were taken at 20 hpi. Black arrows $=$ haustoria and red arrows $=$ papillae . 
Zoospore viability and germination were enhanced in highly susceptible hosts but zoospore PCD was triggered by infection-resistant plants (Galiana et al. 2005). We showed that overexpression of PsTatD4 in P. sojae impaired virulence even when a susceptible host soybean cultivar served as host. Because overexpression of PsTatD4 in P. sojae increased the numbers of TUNEL-positive cells, we suggest that reduction of virulence likely due to that cell death is promoted by overaccumulation of PsTatD4. Regulation of PCD in both pathogen and plant sides influences outcomes of plant-pathogen interactions. It may be possible to develop new crop-protection strategies by manipulating pathogen PCD, via synthesis of chemicals affecting such processes, or by engineering plants to express high levels of microbe PCD-induced molecules. Several recent studies have suggested that fungal PCD may mediate fungus-plant interactions (Ramsdale 2008; Sharon et al. 2009; Sharon and Shlezinger 2013). However, the genetic and

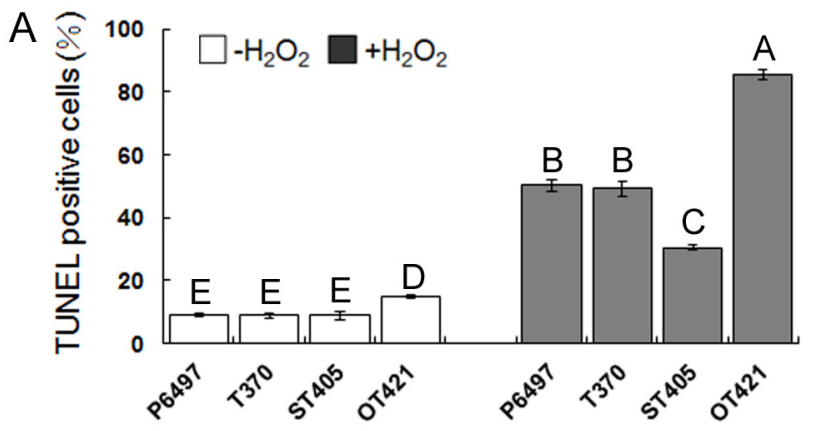

B
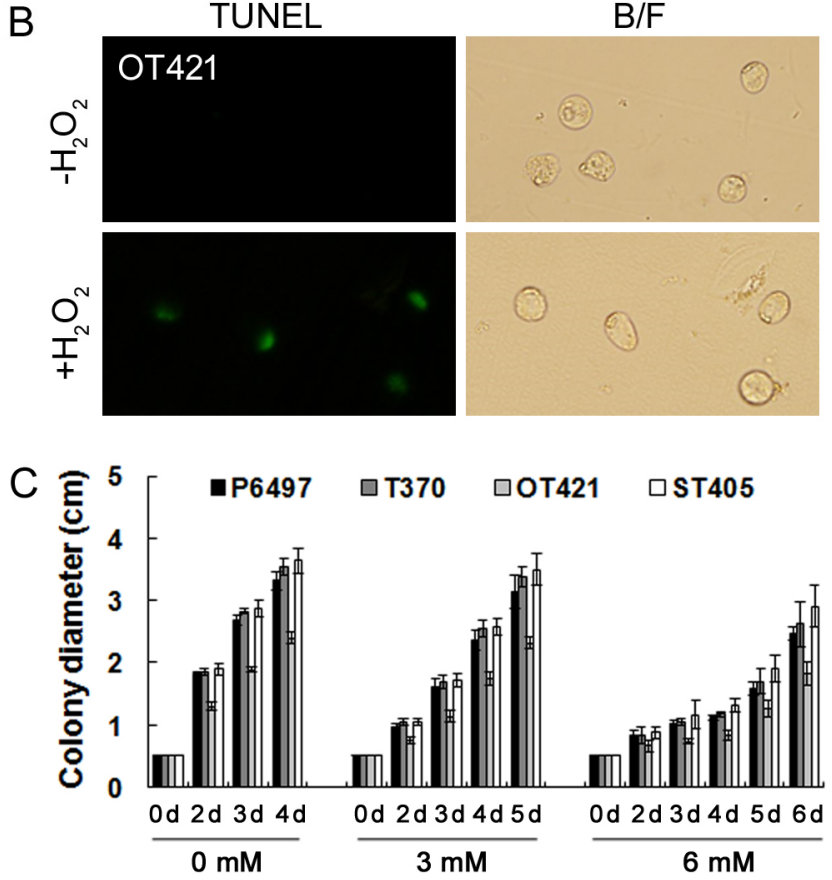

Fig. 7. PsTatD4 is involved in programmed cell death of Phytophthora sojae. A, Terminal dUTP nick end-labeling (TUNEL)-positive cell numbers of the wild-type, control (T370), PsTatD4-overexpressing (OT421), and PsTatD4-silenced (ST405) strains, treated with $\mathrm{H}_{2} \mathrm{O}_{2}$ or not. Bars show mean values with standard errors. Letters A through $\mathrm{E}$ indicates significant difference at $P<0.01$ using Duncan's multiple range analysis. B, TUNEL staining of PsTatD4-overexpressing OT421 cells exposed to 3 $\mathrm{mM} \mathrm{H} \mathrm{H}_{2} \mathrm{O}_{2}$ (lower panel) or not (upper panel). TUNEL-positive cells showed green fluorescence. $\mathrm{B} / \mathrm{F}=$ bright field. $\mathbf{C}$, Mycelial growth of $P$. sojae strains upon $\mathrm{H}_{2} \mathrm{O}_{2}$ stress. Colony diameters were measured after 0 , 2,3 , and 4 days in treatment of $\mathrm{H}_{2} \mathrm{O}_{2}(0$ to $6 \mathrm{mM})$. The experiment was repeated three times and bars show the standard errors. biochemical fundamentals of Phytophthora PCD remain largely unknown. Notably, we found that PsTatD4 expression was weak in the early stages of infection but higher later. This suggests that PsTatD4-mediated cell death might not develop during initial infection but perhaps is required at later infection stages. This contrasts with data on the necrotrophic plant pathogen $B$. cinerea, which experiences PCD during the early interaction with host plants and fully recoveries when spreading lesions start to develop (Shlezinger et al. 2011). We infer that variant enrollment of PCD in different infection stages is likely due to the disease cycle characterizations of $P$. sojae.

Both the zoospores and sporangia of Phytophthora pathogens play major roles in infection and the spread of disease. The zoospores produced from sporangia are important for $P$. sojae. During early stages of infection, zoospores encyst on the surface of soybean tissues, and germ tubes develop directly from cysts to penetrate host cells and establish successful infections (Tyler 2007). We showed that PsTatD4 was weakly expressed at early infective stages. The reduced virulence of PsTatD4overexpressing strains may be attributable to excessive cell death during initial infection, consistent with observations on C. gloeosporioides infection (Nesher et al. 2008). During later stages of infection, infected host tissues were killed when pathogens entered the necrotrophic state. We found that PsTatD4 was highly expressed at this time. Also, PsTatD4 overexpression or silencing enhanced or suppressed, respectively, sporulation and zoospore production. Together, we infer that $P$. sojae may escape from cell death in the early infection stages for successful colonization in the host and generate cell death to turn into a program of sporangia and zoospores production, in which expression of PsTatD4 is switched. In this context, PsTatD4 expression plays an important role. This hypothesis is amenable to testing in other significant oomycete pathogens.

In the present study, overexpression of PsTatD4 (fused with GFP or not) clearly altered the cell phenotype. Growth and virulence were reduced, production of sporangia and zoospores increased, and cell death was induced. However, impairment of PsTatD4 expression in transgenic cell lines reduced only sporangial and zoospore production levels, and the numbers of $\mathrm{H}_{2} \mathrm{O}_{2}$-induced TUNEL-positive cells. Because four TatD genes were identified in P. sojae and gene PsTatD4 is specifically silenced in transgenic lines, the other TatD proteins may be redundant in the present context. Another possible explanation is that expression of PsTatD4 was only partially silenced.

In conclusion, we have identified an oomycete-specific TatD enzyme of $P$. sojae. The protein exhibits DNase activity, is localized to the cytoplasm, and enters the nucleus after exposure of cells to $\mathrm{H}_{2} \mathrm{O}_{2}$. Thus, the protein may be involved in apoptosis. The protein positively influences sporulation and represses pathogenesis. In general, apoptosis likely plays different roles in early and later infection stages for this pathogen to successfully adapt to its infectious cycle, in which expression of PsTatD4 is switched. We present insights into the basic biological functions of PCD, and identify targets of disease control in which the PCD of pathogens may be selectively manipulated.

\section{MATERIALS AND METHODS}

Bioinformatic analyses.

To identify the TatD proteins in oomycetes, we obtained the known TatD proteins from GenBank. These proteins included all the known members from Homo sapiens (National Center for Biotechnology Information: NP_114415.1, NP_055575.3, and NP_001036017.1), E. coli (YP_026271.1, NP_287234.1, 
and YP_026291.2), A. thaliana (NP_190807.3, NP_974418.1, NP_187000.1, and NP_568352.1), S. cerevisiae (NP_009498.1 and NP_013989.2), and T. brucei (Gannavaram and Debrabant 2012). Databases for oomycetes were obtained from their original sources: Joint Genome Institute for $P$. sojae, $P$. ramorum and $P$. capsici, Broad Institute for $P$. infestans, for Hyaloperonospora arabidopsidis, and the Pythium Genome Database for Pythium ultimum. The retrieved TatD proteins were used as the query to search the oomycetes databases (whole genome, the predicted proteins and genes) by BlastP and tBlastN algorithms (Altschul et al. 1990). Significant hits (E value $<1 \mathrm{e}-5$ ) were checked for the presence of an obvious TatD-related DNase domain using Pfam (Finn et al. 2008). Proteins with a significant DNase domain were considered as TatD candidates in oomycetes. All the TatD proteins derived from the six oomycetes, E. coli, S. cerevisiae. T. brucei, Homo sapiens, and A. thaliana were aligned by performing the ClustalX program
(Thompson et al. 1997) under the default settings. The phylogenetic tree of TatD proteins was constructed using MEGA 4.1 (Tamura et al. 2007) with the neighbor joining method and 1,000 replicates for bootstrap analysis.

Expression of PsTatD4 in bacteria, and nuclease assays.

PsTatD4 was PCR-amplified using the primers PsTatD4BamHIF and PsTatD4HindIIIR (all used primers are introduced in Supplementary Table S1) and ligated into plasmid pET-32a(+) (Invitrogen). The H186A and H215A mutants in PsTatD4 were introduced by overlapping PCR with the indicated primers and confirmed by sequencing (GenScript). The vector pET-32a(+) cloning sites (BamHI and HindIII) were used for producing fusion proteins containing a histidinetagged Trx (LaVallie et al. 1993). The empty vector expressing a histidine-tagged Trx at approximately $19 \mathrm{kDa}$ was used as control lysate. Recombinant proteins expressed in $E$. coli were

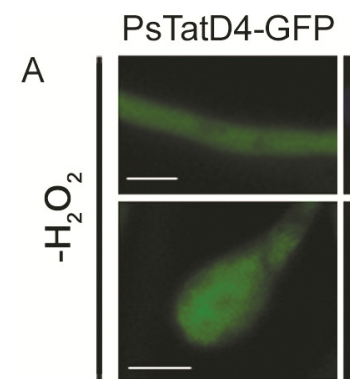

PsTatD4-GFP

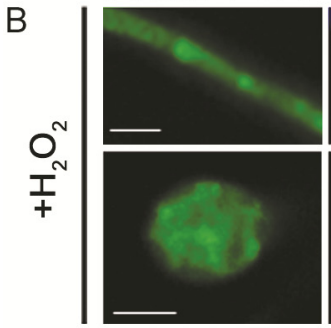

GFP

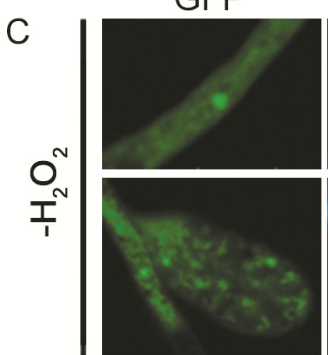

GFP

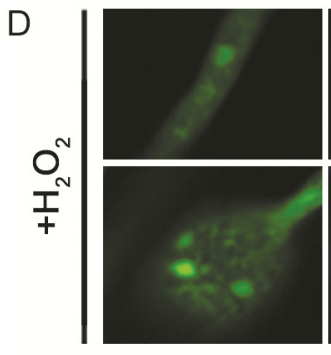

\section{DAPI}

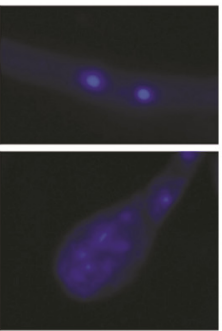

DAPI

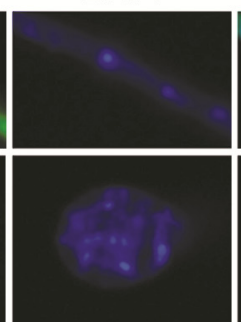

DAPI

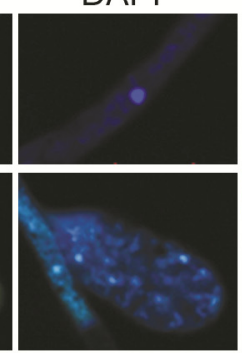

DAPI

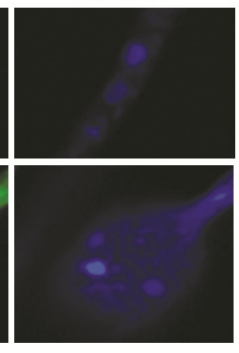

Merged

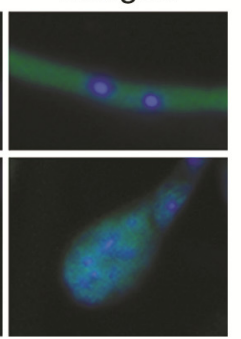

Merged

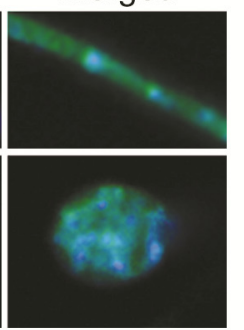

Merged

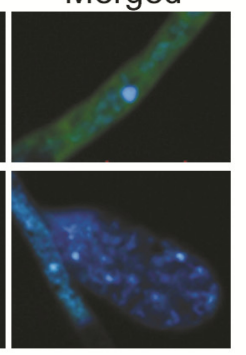

Merged

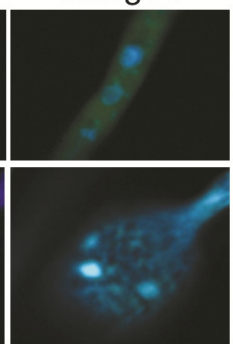

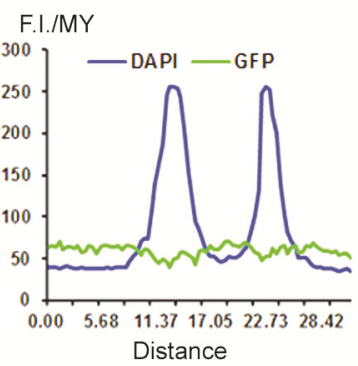
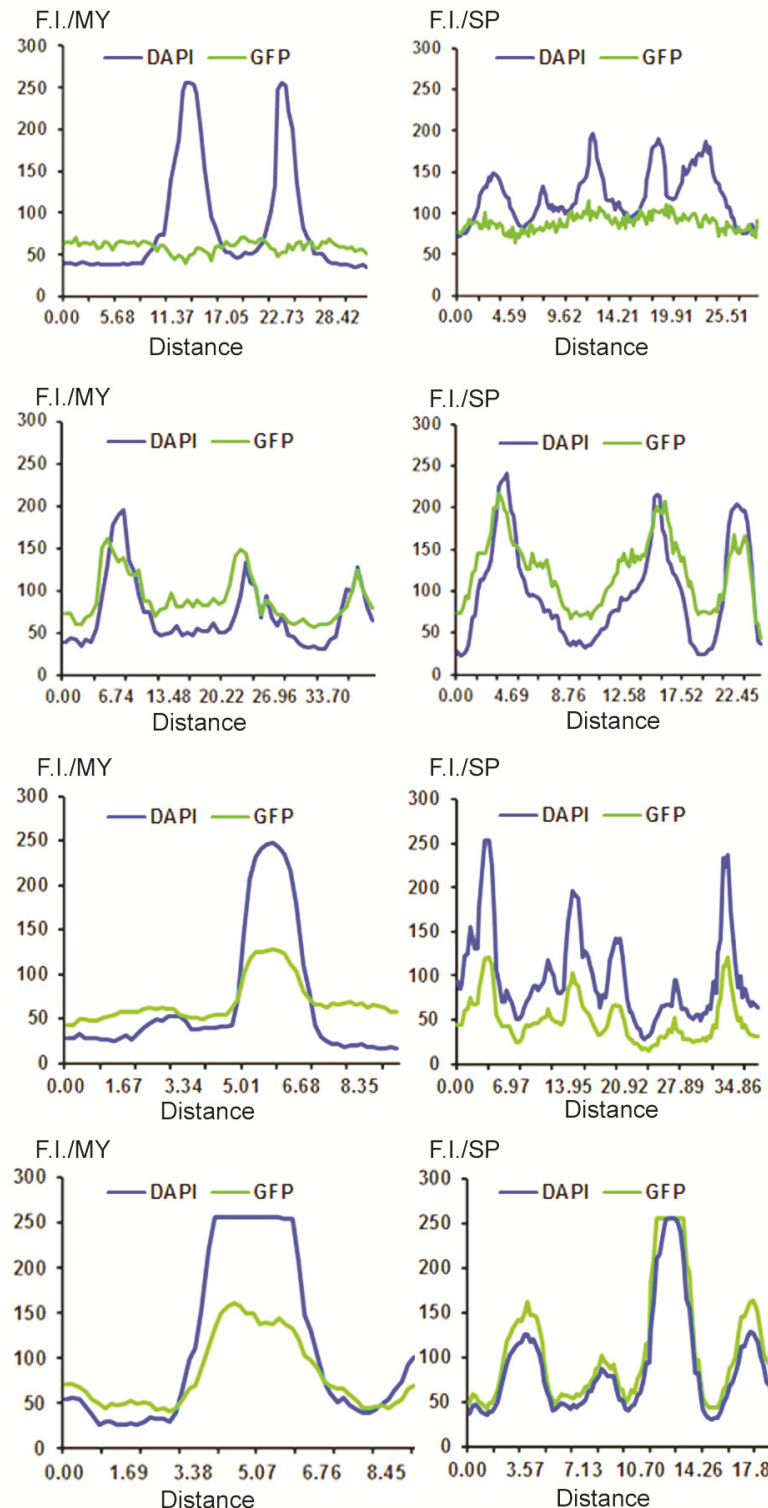
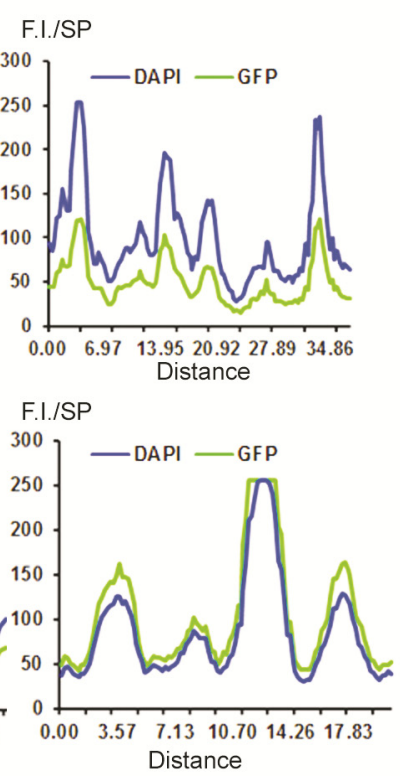

Fig. 8. Nuclear translocation of PsTatD4 during apoptosis. Confocal micrographs showing the subcellular localizations of PsTatD4-green fluorescent protein (GFP) A, absence and $\mathbf{B}$, presence of $\mathrm{H}_{2} \mathrm{O}_{2}$; and GFP alone $\mathbf{C}$, absence and $\mathbf{D}$, presence of $\mathrm{H}_{2} \mathrm{O}_{2}$. The hyphae (upper panel) and sporangia (lower panel) are shown for each treatment. To visualize nuclear regions, 4',6-diamidino-2-phenylindole (DAPI) staining was used (middle column). The right graph represents the fluorescence intensity (F.I.) expressed in arbitrary units along the y-axis, and the length of the transect along which the fluorescence measurements were gathered is indicated along the $\mathrm{x}=\mathrm{axis}$ in microns (Distance). Blue line $=$ DAPI fluorescence intensity, green line $=\mathrm{GFP}$ fluorescence intensity, MY mycelia, and $\mathrm{SP}=$ sporangia. Bars $=10 \mu \mathrm{m}$. 
purified in the native state via $\mathrm{Ni}$-agarose column chromatography for six $6 \times$ His-tagged protein preparations using the manufacturer's protocol (Qiagen). Proteins of a control lysate, purified enzyme, and mutants were examined by sodium dodecyl sulfate polyacrylamide gel electrophoresis (SDS-PAGE). The DNase assay involved incubation of PsTatD4/mutants and DNA substrates in $50 \mathrm{mM}$ Tris (pH 8.0) with $5 \mathrm{mM} \mathrm{MgCl}$ for $30 \mathrm{~min}$ at $30^{\circ} \mathrm{C}$. The substrates were pET32a(+)::PsTatD4 plasmid and Phytophthora sojae genome DNA with a final concentration at $40 \mathrm{ng} / \mu \mathrm{l}$. Cleavage products were resolved using $1.0 \%$ (wt/vol) agarose gel electrophoresis and stained with ethidium bromide.

\section{Plasmid construction and manipulation of $P$. sojae.}

To generate pHamPsTatD4 for $P$. sojae manipulation, including gene overexpression and silencing, the PsTatD4 gene was amplified by PCR using primers PsTatD4F and PsTatD4R with a $6 \times$ His encoded sequence in PsTatD4R $5^{\prime}$ terminal. Gene PsTatD4 was substituted for the NptII gene of pHAMT35N (Judelson et al. 1991). To create pHamGFP, the NptII gene of pHAMT35N was replaced with the AcGFPl gene (AB255038.1) that is amplified using the primers GFPF and GFPR. To generate pHamPsTatD4-GFP, PsTatD4 was amplified using the PsTatD4GFPF and PsTatD4GFPR primers and substituted for the NptII gene of pHAMT35N, and AcGFPl was next amplified using the primers GFPXbaIF and GFPKpnIR and ligated into pHAMT35N containing the PsTatD4 gene. To create the pHamPsTatD4 promoter-GUS, the NptII gene of pHAMT35N was replaced with GUS using the primers GUSF and GUSR, and the Ham 34 promoter PHAMT35N was replaced with the PsTatD4 promoter (a sequence 2,000 bp in length upstream of the PsTatD4 transcription start site). Because the PsTatD4 promoter contained a HindIII restriction site, we performed our construction in two steps. First, the PsTatD4 promoter was PCR-amplified using the primers TatD4pHindIIIF and TatD4pSmaIR, and used to replace the Ham34 promoter. Next, the remaining required sequence was amplified using the primers TatD4pHindIIIF and TatD4pHindIIIR and used to complete construction of PsTatD4 promoter-GUS.

$P$. sojae P6497 was routinely grown and maintained on V8 agar (Erwin and Ribiero 1996) P. sojae transformation was performed as previously described (Dou et al. 2008). P. sojae transformants were selected on V8 medium with $50 \mu \mathrm{g} / \mathrm{ml}$ G418 and mycelia were harvested for extraction of DNA or RNA. Mycelial genomic DNA was used to screen for transgenes via PCR using the primers HamF and HamR. Transcription levels were measured using a qRT-PCR assay of RNA extracts.

Total RNA was extracted using the RNAsimple total RNA kit (Tiangen Biotech following the recommended protocol. qRT-PCR was performed in $20-\mu$ l reactions including $20 \mathrm{ng}$ of cDNA, $0.2 \mu \mathrm{M}$ gene-specific primer of reference $P$. sojae TEF1 gene (EU079791), $10 \mu \mathrm{l}$ of SYBR Premix ExTaq (Takara), and $6.8 \mu \mathrm{l}$ of double-distilled $\mathrm{H}_{2} \mathrm{O}$. PCR reactions were performed on an ABI PRISM 7300 fast Real-Time PCR System (Applied Biosystems) under the following conditions: $95^{\circ} \mathrm{C}$ for $30 \mathrm{~s} ; 40$ cycles at $95^{\circ} \mathrm{C}$ for $5 \mathrm{~s}$ and $60^{\circ} \mathrm{C}$ for $31 \mathrm{~s}$ to calculate cycle threshold $\left(\mathrm{C}_{\mathrm{T}}\right)$ values; followed by a dissociation program of $95^{\circ} \mathrm{C}$ for $15 \mathrm{~s}, 60^{\circ} \mathrm{C}$ for $1 \mathrm{~min}$, and $95^{\circ} \mathrm{C}$ for $15 \mathrm{~s}$ to obtain melt curves. The 7300 System Sequence Detection Software (version 1.4) was used to obtain relative expression levels of each sample. The transcript levels of test genes were determined according to the function $\Delta \mathrm{C}_{\mathrm{T}}=\mathrm{C}_{\mathrm{T}}$ (test gene) $-\mathrm{C}_{\mathrm{T}}$ (reference gene). To compare untreated and treated expression levels, the function $\Delta \Delta \mathrm{C}_{\mathrm{T}}$ was determined using the equation $\Delta \Delta \mathrm{C}_{\mathrm{T}}=\Delta \mathrm{C}_{\mathrm{T}}$ (treatment) $-\Delta \mathrm{C}_{\mathrm{T}}$ (control), where the control was mock-treated $P$. sojae P6497 mycelia. The induc- tion ratio of treatment/control was then calculated by the equation $2^{-\Delta \Delta C T}$.

\section{Histochemical staining of GUS.}

Two independent transgenic lines harboring PsTatD4(p)GUS were stained for GUS using a previously described method modified as follows (Jefferson et al. 1987). Transgenic $P$. sojae and infected plant tissues were incubated at $37^{\circ} \mathrm{C}$ overnight in $1 \mathrm{mM}$ 5-bromo-4-chloro-3-indolyl-b-D-glucuronide in $100 \mathrm{mM}$ sodium phosphate ( $\mathrm{pH} 7.0), 10 \mathrm{mM}$ EDTA, $0.5 \mathrm{mM}$ potassium ferricyanide, $0.5 \mathrm{mM}$ potassium ferrocyanide, $0.3 \%$ ( $\mathrm{vol} / \mathrm{vol}$ ) Triton $\mathrm{X}-100$, and $20 \%$ (vol/vol) methanol. By this method, the endogenous GUS could be eliminated by the presence of methanol (Kosugi et al. 1990; Van West et al. 1999). Recombinant GUS activity was visualized microscopically.

\section{Western blotting.}

Total protein extracts were prepared in universal lysis buffer (50 mM HEPES, $150 \mathrm{mM} \mathrm{KCl,} 1 \mathrm{mM}$ EDTA, and 1\% Triton $\mathrm{X}-100[\mathrm{pH} 7.5])$. Each lysate $(1,000 \mu \mathrm{l})$ was supplemented with $5 \mu \mathrm{l}$ of $10 \%$ Triton $\mathrm{X}-100,1 \mu \mathrm{l}$ of $1 \mathrm{M}$ dithiothreitol, and $20 \mu \mathrm{l}$ of $50 \times$ Protease Inhibitor Cocktail (Roche). The suspensions were mixed and centrifuged at $5,000 \times g$ for 5 to $10 \mathrm{~min}$ at $4{ }^{\circ} \mathrm{C}$. The supernatants were collected and loaded onto $15 \%$ (wt/vol) SDS-PAGE gels and subjected to electrophoresis. Proteins were transferred to polyvinylidene difluoride membranes. Different primary antibodies were used: anti-His monoclonal antibodies (Sigma-Aldrich) for PsTatD4, anti-Actin monoclonal antibodies (Sigma-Aldrich) for $P$. sojae actin, and antiGFP monoclonal antibodies (Sigma-Aldrich) for GFP and PsTatD-GFP. Goat anti-mouse IRDye 800CW (Odyssey, number 926-32210; Li-Cor, Lincoln, NE, U.S.A.) was used as secondary antibodies. Proteins were detected using the Odyssey CLx infrared imaging system (Li-Cor).

\section{Analysis of $P$. sojae development.}

$P$. sojae development was analyzed using previously described methods (LaVallie et al. 1993). To evaluate growth, WT strain P6497 and recombinant derivatives were subcultured twice and then grown on individual agar disks on $10 \%$ V8 agar medium. Colony diameters were measured 4 days later; all experiments were performed at least three times with over four replicates in each experiment. To assay mycelia growth upon oxidative stress, $\mathrm{H}_{2} \mathrm{O}_{2}$ at indicated concentrations was added to solidified $10 \% \mathrm{~V} 8$ medium; then, colony diameters were measured 2 to 6 days later. To explore zoosporulation, agar disks from the edges of actively growing cultures were cultured in $2 \mathrm{ml}$ of $10 \% \mathrm{~V} 8$ juice at $25^{\circ} \mathrm{C}$ in the dark for $30 \mathrm{~h}$. Hyphae were washed three times in $2 \mathrm{ml}$ of sterile distilled water, and a further aliquot of $2 \mathrm{ml}$ of sterile distilled water was added to each plate to induce sporangial development in the dark at $25^{\circ} \mathrm{C}$. Sporangial numbers were recorded and zoospores were counted at indicated time. Data were analyzed using a $t$ test. Zoospore suspensions were vortexed for $90 \mathrm{~s}$ to induce encystment and cyst suspensions were incubated in $5 \% \mathrm{~V} 8$ liquid at $25^{\circ} \mathrm{C}$ for $2 \mathrm{~h}$ to induce germination.

\section{$P$. sojae infection assays.}

Virulence levels were determined by infecting etiolated soybean (susceptible Williams) seedlings and leaves with $2 \mu \mathrm{l}$ of zoospore suspension (100 zoospores/ $\mu \mathrm{l})$. Lesion lengths of etiolated seedlings were measured at 36 hpi and leaf lesion diameters on leaves at $30 \mathrm{hpi}$. All experiments were repeated at least three times, and the data were analyzed using a $t$ test. Trypan blue staining was performed as described previously (Koch and Slusarenko 1990). 


\section{TUNEL assays.}

$P$. sojae zoospores were incubated in $3 \mathrm{mM} \mathrm{H}_{2} \mathrm{O}_{2}$, washed with phosphate-buffered saline $2 \mathrm{~h}$ later, and assayed using One Step TUNEL apoptosis assay kits (Beyotime, C1086) following the manufacturer's protocol. Stained cells were imaged and counted using an Olympus 1 X71 inverted microscope registering fluorescence at 450 to $500 \mathrm{~nm}$. TUNEL-positive cell proportions were determined after examining at least 300 cells in each of three independent experiments. Duncan's multiple range test was used for statistical analysis.

\section{Microscopy.}

To probe for nuclei, $2 \mu \mathrm{M}$ 4',6-diamidino-2-phenylindole dilactate (Invitrogen) was used. Fluorescent mycelia and sporangia expressing GFP and PsTatD4-GFP were examined with the aid of a ZEISS LSM700 confocal laser-scanning microscope. ZEN 2010 software was used for fluorescence intensity analysis. An Olympus IX71 instrument was used to count sporangia and to monitor trypan blue staining during infection.

\section{ACKNOWLEDGMENTS}

This project was supported by grants from the National Natural Science Foundation of China (31171831 and 31371894) and Natural Science Foundation of Jiangsu Province (BK2012027).

\section{LITERATURE CITED}

Altschul, S. F., Gish, W., Miller, W., Myers, E. W., and Lipman, D. J. 1990. Basic local alignment search tool. J. Mol. Biol. 215:403-410.

Barhoom, S., and Sharon, A. 2007. Bcl-2 proteins link programmed cell death with growth and morphogenetic adaptations in the fungal plant pathogen Colletotrichum gloeosporioides. Fungal Genet. Biol. 44:32-43.

BoseDasgupta, S., Das, B. B., Sengupta, S., Ganguly, A., Roy, A., Dey, S., Tripathi, G., Dinda, B., and Majumder, H. K. 2008. The caspase-independent algorithm of programmed cell death in Leishmania induced by baicalein: The role of LdEndoG, LdFEN-1 and LdTatD as a DNA 'degradesome'. Cell Death Differ. 15:1629-1640.

del Pozo, O., and Lam, E. 1998. Caspases and programmed cell death in the hypersensitive response of plants to pathogens. Curr. Biol. 8:R896R896.

Dou, D. L., Kale, S. D., Wang, X. L., Chen, Y. B., Wang, Q. Q., Wang, X., Jiang, R. H. Y., Arredondo, F. D., Anderson, R. G., Thakur, P. B., McDowell, J. M., Wang, Y. C., and Tyler, B. M. 2008. Conserved C-terminal motifs required for avirulence and suppression of cell death by Phytophthora sojae effector Avr1b. Plant Cell 20:1118-1133.

Erwin, D. C., and Ribiero. O. K. 1996. Phytophthora Diseases Worldwide. American Phytopathological Society Press, St. Paul, MN, U.S.A.

Finn, R. D., Tate, J., Mistry, J., Coggill, P. C., Sammut, S. J., Hotz, H. R., Ceric, G., Forslund, K., Eddy, S. R., Sonnhammer, E. L. L., and Bateman, A. 2008. The Pfam protein families database. Nucleic Acids Res. 36:D281-D288.

Galiana, E., Riviere, M. P., Pagnotta, S., Baudouin, E., Panabieres, F., Gounon, P., and Boudier, L. 2005. Plant-induced cell death in the oomycete pathogen Phytophthora parasitica. Cell Microbiol. 7:13651378.

Galluzzi, L., Aaronson, S. A., Abrams, J., Alnemri, E. S., Andrews, D. W., Baehrecke, E. H., Bazan, N. G., Blagosklonny, M. V., Blomgren, K., Borner, C., Bredesen, D. E., Brenner, C., Castedo, M., Cidlowski, J. A., Ciechanover, A., Cohen, G. M., De Laurenzi, V., De Maria, R., Deshmukh, M., Dynlacht, B. D., El-Deiry, W. S., Flavell, R. A., Fulda, S., Garrido, C., Golstein, P., Gougeon, M. L., Green, D. R., Gronemeyer, H., Hajnoczky, G., Hardwick, J. M., Hengartner, M. O., Ichijo, H., Jaattela, M., Kepp, O., Kimchi, A., Klionsky, D. J., Knight, R. A., Kornbluth, S., Kumar, S., Levine, B., Lipton, S. A., Lugli, E., Madeo, F., Malomi, W., Marine, J. C., Martin, S. J., Medema, J. P., Mehlen, P., Melino, G., Moll, U. M., Morselli, E., Nagata, S., Nicholson, D. W., Nicotera, P., Nunez, G., Oren, M., Penninger, J., Pervaiz, S., Peter, M. E., Piacentini, M., Prehn, J. H., Puthalakath, H., Rabinovich, G. A., Rizzuto, R., Rodrigues, C. M., Rubinsztein, D. C., Rudel, T., Scorrano, L., Simon, H. U., Steller, H., Tschopp, J., Tsujimoto, Y., Vandenabeele, P., Vitale, I., Vousden, K. H., Youle, R. J., Yuan, J., Zhivotovsky, B., and Kroemer, G. 2009. Guidelines for the use and interpretation of assays for monitoring cell death in higher eukaryotes. Cell Death Differ. 16:1093-1107.
Gannavaram, S., and Debrabant, A. 2012. Involvement of TatD nuclease during programmed cell death in the protozoan parasite Trypanosoma brucei. Mol. Microbiol. 83:926-935.

Jefferson, R. A., Kavanagh, T. A., and Bevan, M. W. 1987. GUS fusions beta-glucuronidase as a sensitive and versatile gene fusion marker in higher plants. EMBO (Eur. Mol. Biol. Organ.) J. 6:3901-3907.

Judelson, H. S., and Blanco, F. A. 2005. The spores of Phytophthora: Weapons of the plant destroyer. Nat. Rev. Microbiol. 3:47-58.

Judelson, H. S., Tyler, B. M., and Michelmore, R. W. 1991. Transformation of the Oomycete Pathogen, Phytophthora infestans. Mol. PlantMicrobe Interact. 4:602-607.

Koch, E., and Slusarenko, A. 1990. Arabidopsis is susceptible to infection by a downy mildew fungus. Plant Cell 2:437-445.

Kosugi, S., Ohashi, Y., Nakajima, K., and Arai, Y. 1990. An improved assay for beta-glucuronidase in transformed cells: Methanol almost completely suppresses a putative endogenous beta-glucuronidase activity. Plant Sci. 70:133-140.

Lam, E. 2004. Controlled cell death, plant survival and development. Nat. Rev. Mol. Cell Biol. 5:305-315.

LaVallie, E. R., DiBlasio, E. A., Kovacic, S., Grant, K. L., Schendel, P. F., and McCoy, J. M. 1993. A thioredoxin gene fusion expression system that circumvents inclusion body formation in the $E$. coli cytoplasm. Biotechnology 11:187-193.

Liu, X. S., Zou, H., Widlak, P., Garrard, W., and Wang, X. D. 1999. Activation of the apoptotic endonuclease DFF40 (caspase-activated DNase or nuclease) Oligomerization and direct interaction with histone H1. J. Biol. Chem. 274:13836-13840.

Lyon, C. J., Evans, C. J., Bill, B. R., Otsuka, A. J., and Aguilera, R. J. 2000. The $C$-elegans apoptotic nuclease NUC-1 is related in sequence and activity to mammalian DNase II. Gene 252:147-154.

Madeo, F., Frohlich, E., Ligr, M., Grey, M., Sigrist, S. J., Wolf, D. H., and Frohlich, K. U. 1999. Oxygen stress: A regulator of apoptosis in yeast. J. Cell Biol. 145:757-767.

McLeod, A., Fry, B. A., Zuluaga, A. P., Myers, K. L., and Fry, W. E. 2008. Toward improvements of oomycete transformation protocols. J. Eukaryotic Microbiol. 55:103-109.

Mittler, R., and Lam, E. 1996. Sacrifice in the face of foes: Pathogeninduced programmed cell death in plants. Trends Microbiol. 4:10-15.

Narasimhan, M. L., Damsz, B., Coca, M. A., Ibeas, J. I., Yun, D. J., Pardo, J. M., Hasegawa, P. M., and Bressan, R. A. 2001. A plant defense response effector induces microbial apoptosis. Mol. Cell 8:1153-1153.

Nesher, I., Barhoom, S., and Sharon, A. 2008. Cell cycle and cell death are not necessary for appressorium formation and plant infection in the fungal plant pathogen Colletotrichum gloeosporioides. BMC Biol. 6:9.

Nicholson, D. W., and Thornberry, N. A. 1997. Caspases: Killer proteases. Trends Biochem. Sci. 22:299-306.

Parrish, J. Z., and Xue, D. 2003. Functional genomic analysis of apoptotic DNA degradation in C. elegans. Mol. Cell 11:987-996.

Qiu, J., Yoon, J. H., and Shen, B. 2005. Search for apoptotic nucleases in yeast: Role of Tat-D nuclease in apoptotic DNA degradation. The J. Biol. Chem. 280:15370-15379.

Ramsdale, M. 2008. Programmed cell death in pathogenic fungi. Biochim. Biophys. Acta 1783:1369-1380.

Rossman, A. Y., and Palm, M. E. 2006. Why are Phytophthora and other oomycota not true fungi? Outlooks Pest. Manage. 17:217-219.

Sharon, A., and Shlezinger, N. 2013. Fungi infecting plants and animals: Killers, non-killers, and cell death. PLoS Pathog. 9:8. Published online.

Sharon, A., Finkelstein, A., Shlezinger, N., and Hatam, I. 2009. Fungal apoptosis: Function, genes and gene function. FEMS (Fed. Eur. Microbiol. Soc.) Microbiol. Rev. 33:833-854.

Shlezinger, N., Minz, A., Gur, Y., Hatam, I., Dagdas, Y. F., Talbot, N. J., and Sharon, A. 2011. Anti-apoptotic machinery protects the necrotrophic fungus Botrytis cinerea from host-induced apoptotic-like cell death during plant infection. PLoS Pathog. 7:e1002185. Published online.

Shlezinger, N., Goldfinger, N., and Sharon, A. 2012. Apoptotic-like programed cell death in fungi: The benefits in filamentous species. Front. Oncol. 2:97.

Song, T. Q., Kale, S. D., Arredondo, F. D., Shen, D. Y., Su, L. M., Liu, L., Wu, Y. R., Wang, Y. C., Dou, D. L., and Tyler, B. M. 2013. Two RxLR avirulence genes in Phytophthora sojae determine soybean rps1k-mediated disease resistance. Mol. Plant-Microbe Interact. 26:711-720.

Tamura, K., Dudley, J., Nei, M., and Kumar, S. 2007. MEGA4: Molecular evolutionary genetics analysis (MEGA) software version 4.0. Mol. Biol. Evol. 24:1596-1599.

Thompson, J. D., Gibson, T. J., Plewniak, F., Jeanmougin, F., and Higgins, D. G. 1997. The CLUSTAL_X windows interface: Flexible strategies for multiple sequence alignment aided by quality analysis tools. $\mathrm{Nu}-$ cleic Acids Res. 25:4876-4882.

Tyler, B. M. 2007. Phytophthora sojae: Root rot pathogen of soybean and 
model oomycete. Mol. Plant Pathol. 8:1-8.

van Damme, M., Cano, L. M., Oliva, R., Schornack, S., Segretin, M. E., Kamoun, S., and Raffaele, S. 2011. Evolutionary and functional dynamics of oomycete effector genes. Pages 101-120 in: Effectors in PlantMicrobe Interactions. Wiley-Blackwell. Hoboken, NJ, U.S.A.

Van West, P., Reid, B., Campbell, T. A., Sandrock, R. W., Fry, W. E., Kamoun, S., and Gow, N. A. 1999. Green fluorescent protein (GFP) as a reporter gene for the plant pathogenic oomycete Phytophthora palmivora. FEMS (Fed. Eur. Microbiol. Soc.) Microbiol. Lett. 178:7180.

Veneault-Fourrey, C., Barooah, M., Egan, M., Wakley, G., and Talbot, N. J. 2006. Autophagic fungal cell death is necessary for infection by the rice blast fungus. Science 312:580-583.

Walker, C. A., and van Westj, P. 2007. Zoospore development in the oomycetes. Fungal Biol. Rev. 21:10-18.

Weiner, J. H., Bilous, P. T., Shaw, G. M., Lubitz, S. P., Frost, L., Thomas,
G. H., Cole, J. A., and Turner, R. J. 1998. A novel and ubiquitous system for membrane targeting and secretion of cofactor-containing proteins. Cell 93:93-101.

Wexler, M., Sargent, F., Jack, R. L., Stanley, N. R., Bogsch, E. G., Robinson, C., Berks, B. C., and Palmer, T. 2000. TatD is a cytoplasmic protein with DNase activity. No requirement for TatD family proteins in sec-independent protein export. J. Biol. Chem. 275:16717-16722.

Williams, B., and Dickman, M. 2008. Plant programmed cell death: Can't live with it; can't live without it. Mol. Plant Pathol. 9:531-544.

\section{AUTHOR-RECOMMENDED INTERNET RESOURCES}

Joint Genome Institute Tree of Life database: genome.jgi-psf.org Broad Institute website: www.broadinstitute.org

Pythium Genome database: pythium.plantbiology.msu.edu 